\title{
Os objetos autísticos complexos são nocivos?
}

Are complex autistic objects harmful?

?Los objetos autísticos complejos son nocivos?

J-C Maleval

0 que fazer com os objetos autísticos? Eles participam da construção subjetiva ou entravam o desenvolvimento da criança? São vetores de abertura ou de fechamento? Trata-se de um debate que divide os especialistas. A maior parte deles considera que o objeto autístico deve ser largado para permitir que o sujeito evolua. Entretanto, mesmo os partidários de métodos reeducativos mostram-se prudentes e, frequentemente, aconselham a não retirá-los precipitadamente. Os mais favoráveis ao respeito e à utilização dos objetos autísticos são os autistas de alto desempenho, quando podem relatar sua experiência (Grandin, [1995] 1997, p. 115). Orientar-se, levando em conta a diversidade dessas opiniōes, exige um aprofundamento acerca das funções do objeto autístico. Por que o sujeito parece tão ligado a ele? A que serve esse objeto? Pode o sujeito viver sem isso?

Conhecemos as respostas de Tustin, a primeira clínica a isolar o objeto autístico e extrair certas funções dele. Ela sublinha, por vezes muito fortemente, a dimensão patológica desses objetos. Segundo ela, tais objetos "se opõem à vida e à criatividade; trazem em si a destruição e o desespero" (Tustin, [1981] 1986, p. 90) ${ }^{1}$. Acrescenta que, sendo vividos como partes do corpo, "são sentidos como instantaneamente disponíveis e não ajudam a criança, então, em sua aprendizagem da espera. Não ajudam, também, a suportar a tensão e a adiar a ação - o que é essencial para as atividades simbólicas. Os objetos autísticos", acrescenta, "tem outro efeito devastador: as sensações-objeto e as sensações-forma não são substitutos temporais da mãe, eles a substituem de modo permanente. Os cuidados da mãe se tornam, por isso, nulos e sem efeito" (Tustin, [1990] 1992, p. 137)².

\footnotetext{
N. T.: título do texto original: "Les objets autistiques complexes sont-ils nocifs?". Será publicado em L'autiste, son double et ses objets. Presses Universitaires de Rennes, 2009, p. 161-189. Tradução: Vera Lopes Besset; revisão: Alain Besset.

Psicanalista, membro da "Ecole de la Cause freudienne" e da Associação Mundial de Psicanálise, professor de psicologia clínica do Laboratório de Psicopatologia e Clínica psicanalítica. Universidade Rennes 2 - CS 24307 - 35043 Rennes Cedex.

N. T.: No original: "s’opposent à la vie et à la créativité; ils portent en eux la destruction et le désespoir". Tustin F. Les états autistiques chez l'enfant. (1981). Paris: Seuil, 1986, p. 90.

2 N. T.: no original: "sont ressentis comme instantanément disponibles et n'aident donc pas l'enfant dans son apprentissage de l'attente. Ils ne l'aident pas non plus à supporter la tension et à différer l'action - ce qui est essentiel pour les activités symboliques. Les objets autistiques, ajoute-t-elle, ont un autre effet dévastateur: les sensations-objets et les sensationsformes ne sont pas des substituts temporaires de la mère, elles la remplacent de façon permanente. Ses soins deviennent de ce fait nuls et non avenus". Tustin F. Autisme et protection. (1990). Paris: Seuil, 1992, p. 137.
} 
No que concerne às técnicas de reeducação do comportamento, os objetos autísticos também não são bem vistos. Quando não são questionados em suas funções, são considerados anomalias comportamentais, de modo que seria preciso, sem dúvida, dedicar-se a corrigi-las. No melhor dos casos, o uso de um método progressivo atenuará a violência feita ao sujeito. Uma criança autista de 4 anos mostrava, há três anos, um "apego inadaptado" a seu cobertor. Buscou-se tirar isso dela, brutalmente, mas se constatou que um "desamparo agudo tomava conta dela”. Não importa: vamos ajudá-la em detrimento dela própria. Indicou-se à mãe que reduzisse progressivamente o cobertor, cortando alguns pedaços toda noite. "Ele é rapidamente encurtado", nos disse, "e, ao cabo de duas semanas, mais ou menos, 'o cobertor' estava reduzido a alguns fios, formando um nó”. A criança terminou por abandonálo. Entretanto, incorrigível, se pôs a "transportar novos objetos; por exemplo, ônibus de plástico". Procedeu-se do mesmo modo para fazê-la abandoná-los. O desamparo foi menor ao mesmo tempo em que o apego aos novos objetos se mostrou menos intenso. A observação não diz se o desinvestimento dos objetos se acompanha de um real proveito para a criança, pois os autores consideram evidente que se deve considerar uma tal normalização como um progresso. Notemos que o dito "cobertor" mereceria um exame que pudesse distingui-lo como objeto transicional ou objeto autístico, mas esses terapeutas só conhecem "apegos inadaptados a objetos" (Hemsley et coll, [1978] 1991, p. 479), de modo que estavam prontos a erradicar tanto um quanto outro tipo de objeto. Para eles, o ato de chupar o dedo era, sem dúvida, rapidamente visto como um mau hábito.

Entretanto, todos os sujeitos autistas convergem, em seus ditos e em seus comportamentos, na indicação de que certos objetos são uma ajuda preciosa para eles. "Por algum motivo importante", escreve Sellin, "encontro segurança somente nos objetos"; "Desde minha mais tenra infância", observa Grandin, "interesso-me muito mais pelas máquinas do que por meus semelhantes". Williams é ainda mais preciso: "Para mim, as pessoas que eu amava eram objetos, e esses objetos (ou as coisas que os evocavam) eram minha proteção contra as coisas das quais não gostava, quer dizer, as outras pessoas [...] Comunicar por meio dos objetos era sem perigo". Grandin insiste sobre o erro que muitos educadores de crianças autistas cometem quando querem erradicar a fixação e as "obsessões" dessas crianças. Seria melhor, diz ela, apoiando-se em sua experiência pessoal, "alargar o campo obsessivo e tentar orientar o interesse manifestado pelo autista na direção de atividades construtivas. Por exemplo, se uma criança é fanática por barcos, é preciso tirar proveito dessa obsessão para incitá-la a ler, estudar Matemática, consultar 
livros especializados e a resolver problemas de velocidade e de nós. As fixações são uma fonte de motivaçôes. Leo Kanner declarou, um dia, que o caminho do sucesso para alguns autistas consistia em transformar uma fixação em carreira profissional" (Grandin, [1995] 1997, p. 115). Por outro lado, a maior parte dos clínicos e dos educadores estão de acordo em considerar que a criança autista tem necessidade de apoiar seu pensamento em elementos concretos que lhe permitam organizá-lo progressivamente. Mesmo aqueles que consideram o autismo como um transtorno invasor do desenvolvimento constatam que "eles aprendem mais a partir dos objetos do que das pessoas" (Peeters, [1994] 1996, p. 157). O autor, que exalta o método TEACCH, observa que os comportamentos estereotipados dos autistas têm "uma função evidente". As pessoas atingidas pelo autismo, escreve Peeters, pertinentemente, "querem viver de uma maneira segura e previsível, escapar de situações difíceis demais, fazem questão de se defender, buscam eliminar a angústia e, enfim, querem se estimular e ser gratificadas... Nós queremos verdadeiramente tirar tudo isso delas? prossegue Peeters. Que preço (in)humano será preciso pagar? Numerosos estereótipos são característicos dessas pessoas: correspondem a um estilo cognitivo rígido, são previsíveis e deixam os autistas eufóricos. [...] Em resumo, podemos dizer que os autistas têm necessidade deles e que tem direito a isso" (Peeters, [1994] 1996, p. 191). Essas confissões pertinentes, impostas pela clínica, chocam-se, entretanto, com a lógica na qual se inserem: qualquer abordagem do autismo ancorada em uma concepção genética, fundada em uma abordagem normativa do desenvolvimento do sujeito, induz a se opor, cedo ou tarde, à persistência dos estereótipos e dos objetos autísticos.

Apesar de Tustin considerar que esses objetos patológicos devem desaparecer ao longo de um tratamento, constatou que a supressão brutal da proteção que eles dão corre o risco de ter consequências nefastas. "Fico muito preocupada", escreve ela, "quando ouço as pessoas falarem em 'suprimir o autismo', 'curá-lo' ou, ainda, 'furá-lo'. Vi e ouvi falar de crianças que tinham sido tratadas em função de tais concepçôes: haviam se tornado hiperativos ou até mesmo totalmente esquizofrênicos" (Tustin, 1992, p. 37). Desde então, a experiência adquirida confirma que a supressão precipitada do objeto autístico, frequentemente, suscita nas crianças autistas quadros clínicos que são dificilmente diferenciáveis da esquizofrenia.

\section{Função dos objetos autísticos simples}

Em 1972, em uma obra intitulada "Autisme et psychose de l'enfant", Tustin foi a primeira a formular o conceito de objeto autístico. Colocou em evidência, 
de saída, suas funções protetoras e, ao mesmo tempo, patológicas. Prosseguiu com o estudo sobre as especificidades desse objeto em pesquisas ulteriores, nutridas por sua prática psicanalítica com crianças psicóticas, de modo que chegou a uma teorização muito elaborada sobre o objeto autístico.

Em sua primeira abordagem, apoia-se na descoberta do objeto transicional, isolado por Winnicott em 1951 e caracterizado por este como "a primeira posse não-eu" da criança. O objeto autístico seria, em sua perspectiva, uma espécie de precursor do objeto transicional, apresentando a especificidade de ser ainda percebido como "totalmente eu". Considera que, no desenvolvimento normal, o primeiro se funde no segundo.

Sabemos que o objeto transicional aparece no primeiro ano de vida. Encarna-se, mais frequentemente, em coelhos, ursos, chupetas, brinquedos de pelúcias, cobertores, forrinhos, etc. Ele é usado como calmante e contribui facilmente para o adormecimento. Constitui, segundo Winnicott, "uma experiência primitiva normal". Representa o seio materno ou o objeto da primeira relação. $\mathrm{O}$ objeto transicional não está nem sob controle mágico, como o objeto interno kleiniano, nem fora do controle, como a verdadeira mãe. Situa-se "entre dois" - o que Winnicott nomeia uma área transicional. Para esse autor, ele se encontra nos primeiros estágios da ilusão e na origem do simbolismo. Lacan faz dele uma versão da bobina do Fort-Da (Lacan, Séance du 6 Juin 1959) e indica que concebeu o objeto pequeno a seguindo sua pista (Lacan, [1967-1968] 2001, p. 379). Com efeito, o objeto transicional constrói-se em relação à perda: coincide, segundo Winnicott, com uma "certa anulação da onipotência" (Winnicott, [1951] 1969, p. 114), só pode surgir se a mãe chega a desiludir a criança. Além disso, está destinado a um progressivo desinvestimento. Com sua existência, esse objeto materializa a colocação em função da falta que comanda o desejo. "O fato de não ser o seio (ou a mãe ou polegar)", escreve Winnicott, "é tão importante quanto o fato de que representa o seio (ou a mãe)". Esse objeto revela que a perda do objeto primordial de gozo dá lugar a objetos substitutos com os quais o sujeito consegue uma certa satisfação.

Por outro lado, segundo Tustin, os objetos autísticos funcionam como proteção contra a perda: não são substitutos (Tustin, [1981] 1986, p. 122). Afirma que sua função é "impedir o desenvolvimento do grau de consciência da separação corporal" (Tustin, [1990] 1992, p. 132); supõe que eles forjam uma proteção contra um "buraco negro" angustiante relacionado a uma perda vital que afetaria o sujeito e o Outro materno. São objetos usados como se fizessem parte do corpo, para dar sensações de segurança e desviar a atenção, de modo que sua razão de ser essencial seria "suprimir as ameaças de ataque corporal 
e de aniquilação definitiva" (Tustin, [1981] 1986, p. 124). Dá o seguinte exemplo: "No início de seu tratamento, David, uma criança psicótica de dez anos, tinha o hábito de levar um carrinho para cada sessão. Ele o apertava tão fortemente na palma de sua mão que a marca do carro ficava impressa nela. Conforme fui trabalhando com ele, compreendi que David tinha a impressão de que seu carrinho tinha propriedades mágicas e o protegia do perigo. Via-o como uma espécie de talismã ou amuleto, com a única diferença que, apertando-o com força em sua mão, parecia que se tornava um pedaço de seu corpo, um pedaço 'a mais', duro. Mesmo quando colocava o carrinho sobre a mesa, a marca dele ficava profundamente impressa na palma de sua mão e ele tinha, então, o sentimento de que o brinquedo ainda fazia parte de seu corpo e continuava a protegê-lo do perigo" (Tustin, [1981] 1986, p. 118).

Além do fato de serem considerados como parte do próprio corpo, caracterizam-se pelo fato de a criança utilizá-los de uma maneira que não corresponde a suas funçôes. Eles trazem, segundo Tustin, um sentimento de segurança, protegem do "não eu", mas, nos autistas, eles são o resultado "de uma autossensualidade que se tornou excessiva e tomou um caminho desviante e perverso" (Tustin, [1981] 1986, p. 139), se bem que tenham como efeito entravar o desenvolvimento mental da criança. Em resumo, ela os concebe como proteções contra a angústia, que ultrapassa suas funções autoterapêuticas até se tornarem nocivos. Não são "substitutos temporários da mãe", escreve, "eles a substituem de modo permanente, a tal ponto que seus cuidados se tornem 'nulos e sem efeito"” (Tustin, [1990] 1992, p. 137).

Por outro lado, Tustin colocou em evidência, de maneira notável, que o sujeito autista situa-se em uma relação transitivista com seu objeto. "Como Kanner havia compreendido muito bem”, escreve em 1990, "essas crianças não distinguem os indivíduos dos objetos inanimados; tratam todos do mesmo modo - colam-se em um muro ou em uma parte dura do corpo de alguém como se fosse um objeto inanimado ou, ainda, grudam suas costas contra pessoas que sentem em fusão e em equação com as sensações de duração assim engendradas. Trata-se aí de equação adesiva mais do que de identificação adesiva. Essas sensações autoengendradas são de primordial importância para essas crianças. A excessiva concentração delas nas sensações engendradas por seus corpos as torna insensíveis às sensações de aplicabilidade objetiva mais normal. Por exemplo, um grande número deles não tem consciência de se machucar quando cai”. O gozo, não estando regulado pela linguagem, invade o corpo com "sensações autoengendradas" no vocabulário de Tustin, enquanto as percepções carecem de um enquadramento simbólico para estruturá-las. A psicanalista inglesa constata que, na relação do autista ao objeto, funcionam 
fenômenos de identificação imediata que lhe parecem muito primários, resultantes de uma espécie de colagem real que não merece mesmo, segundo ela, serem designadas de identificações. "As crianças autistas", escreve, "cercam-se de objetos duros com os quais se sentem em equação de maneira bidimensional. Não se trata aí de identificação; essas crianças recorrem à dureza do objeto a fim de se colocarem em equação com ele". No caso de considerarmos que a identificação é um fenômeno que opera apoiandose nos significantes, Tustin tem razão de considerar que tal colagem a um objeto para se apropriar de certas propriedades não é exatamente da ordem da identificação. "Esses objetos", prossegue, "não são diferenciados do corpo do sujeito e não são usados por suas funções objetivas, mas pelas sensações de dureza que eles trazem [...]. Um grande número dessas crianças desenvolvem um corpo duro, rígido, musculoso como Esther Bick descreveu. São crianças tensas, que vivem em um mundo bidimensional dominado por sensações de dureza e maciez. Essas sensações extremas desviam a atenção das crianças das sensações apropriadas às sensações da vida cotidiana que elas partilham com outros seres humanos. Isso significa que elas desenvolvem particularidades idiossincráticas a fim de engendrar as sensações protetoras que lhes são próprias. Para o observador comum, essas particularidades estereotipadas parecem desprovidas de sentido. A atenção das crianças autistas é a tal ponto concentrada nessas sensaçóes autoengendradas, que elas parecem surdas ou, até mesmo, cegas" (Tustin, [1990] 1992, p. 35-36).

Tustin enfatiza que o objeto autístico funciona como um duplo do sujeito, mas isso não the parece promissor, ela o relaciona essencialmente com a deficiência das identificações e com as sensações inapropriadas. Constata que o objeto autístico protege da angústia, mas sua perspectiva genética não a incita a explorar prioritariamente os recursos que o sujeito pode tirar disso. A partir daí, segundo ela, a única perspectiva no tratamento analítico é a de se orientar em direção à queda do objeto autístico, até mesmo em direção a sua substituição por um objeto transicional.

Tustin insiste muito no fato de que os objetos autísticos têm uma dureza da qual o sujeito autista busca apropriar-se. Ora, a existência de objetos autísticos simples que não são duros parece pouco contestável: pedaços de pano, laços, fitas, brinquedos de borracha. Nesse caso, com frequência, tratase de objetos dotados de um movimento: ou parecem ter uma dinâmica própria, ventilador, hélice, piões, rodas, etc.; ou o sujeito os movimenta: fita que faz oscilar diante dos olhos, corrente que ele balança, bilhas que escorregam na mão, etc. Por que o autista parece captado pelo movimento de tais objetos, o que observa durante horas? Sem dúvida, por uma razã o 
que Tustin colocou em evidência, não somente a propósito da dureza, mas de algumas outras propriedades dos objetos que o sujeito busca integrar. Por exemplo, uma criança autista tinha escolhido como objeto a torre de um jogo com o fim de adquirir sua altura. Crescer, para esses sujeitos, nota Tustin, "significa retirar pedaços do corpo dos adultos e de outras crianças [...] Eles acreditam que, para se tornarem mais altos, ou mais gordos, ou maiores, ou melhores ou mais fortes, devem colar esses 'pedaços' em seu corpo" (Tustin, [1981] 1986, p. 165). Por outro lado, Tustin nota, de modo pertinente, que as crianças autistas "parecem ter a impressão de que são uma coisa inanimada, vacilante na borda do mundo vivo e do humano. Tornar-se vivo e humano é, para elas, algo de apavorante" (Tustin, [1990] 1992, p. 66). Assim, é do lado dos objetos e não dos seres humanos que fazem as primeiras tentativas para adquirir vida. É em seu duplo protetor que buscam um gozo ao qual é lícito se ligar. Ao mesmo tempo em que a enunciação delas pode ser transferida a um duplo, com frequência, veremos, elas buscam uma dinâmica do lado do duplo. Por vezes, Tustin descreve o fenômeno sem concebê-lo plenamente. Durante a primeira sessão de John, uma criança de três anos e meio, relata que ele permanece impassível. "Ele passava diante de mim", escreve, "sem prestar atenção nenhuma, como se eu não existisse, com exceção de um único momento em que, no escritório, ele me tomou pela mão e me puxou em direção ao pião, que girei para ele. Então, tomado de excitação, debruçou-se para vê-lo rodar. Ao mesmo tempo, fazia rodar seu pênis por meio de sua calça comprida e, com a outra mão, desenhava círculos em torno de sua boca. Isso levava a supor que não ele via muita diferença entre os movimentos do pião e os de seu corpo" (Tustin, [1972] 1977, p. 17)3. Esse extrato da clínica ilustra a relação transitivista que o sujeito mantém com seus objetos, mas também o fato de que o autista busca uma dinâmica por intermédio deles, primeiro, nesse caso, na mão do terapeuta e, depois, no pião. Entretanto, a função dos rodopios não é mais do que, segundo Tustin, uma tentativa de evitar o mundo exterior e de abolição da consciência (Tustin, [1990] 1992, p. 85). Certamente, o duplo é inicialmente usado como barreira autossensual, mas um aspecto mais positivo da apropriação do movimento escapa a Tustin: as crianças autistas, que se experimentam como "inanimadas", encontram em seu duplo objetal uma dinâmica vital essencial, tão manifesta, que desaparece a partir do momento em que elas se desligam do objeto. Tustin não se detém sobre a frequência de objetos dinâmicos entre os objetos autísticos simples.

\footnotetext{
N. T.: no original: "Il passait devant moi, écrit-elle, sans me prêter aucune attention, comme si je n'existais pas, à l'exception d'un seul moment où, dans le bureau, il me prit la main et la tira vers la toupie que je fis tourner pour lui. Là, pris d'excitation, il se pencha en avant pour la voir tourner. En même temps, il faisait tourner son pénis à travers son pantalon et, de l'autre main, décrivait des cercles autour de sa bouche. Ce qui me laissa penser qu'il faisait peu de différence entre les mouvements de la toupie et ceux de son corps". Tustin F. Autisme et psychose de l'enfant. (1972). Paris: Seuil, 1977, p. 17.
} 
Sua perspectiva genética, que baliza as etapas do desenvolvimento do sujeito, focaliza-a nas propriedades nocivas dos objetos autísticos, o que a impede de discernir uma de suas principais funções, colocada em evidência de maneira nítida pelos objetos autísticos complexos. Mostraremos isso adiante, a saber, a busca que o sujeito autista opera pela via de uma animação libidinal de seu ser. Não é surpreendente, então, que muitos objetos autísticos sejam, ao mesmo tempo, duros e dinâmicos, a fim de tratar tanto a imagem do corpo como a animação pulsional.

\section{Objeto autístico ou objeto transicional?}

A automáquina ${ }^{4}$ de Joey e a "máquina de espremer"5 (Sacks, 2008, p. 263) de Temple Grandin constituem, sem dúvida, os dois objetos autísticos complexos mais conhecidos hoje pelos especialistas do autismo. Mais do que o primeiro, o segundo é testemunho de uma autoterapia centrada na construção de um objeto, de eficiência inegável, que persiste na idade adulta, o que parece contradizer radicalmente a concepção de Tustin, segundo a qual o objeto autístico é "devastador", e os que supõem que ele seria um obstáculo a "qualquer elaboração interna" (Lemay, 2004, p. 93) ${ }^{6}$. Todos sabem, entretanto, que a analista inglesa não considerava a máquina de Grandin um objeto autístico. Segundo ela, tratar-se-ia provavelmente de um objeto transicional. Apesar de considerar a distinção entre objeto autístico e objeto transicional sempre útil e possível, "é preciso não esquecer", acrescenta ela, "que eles se fundem por vezes um no outro. Nós poderíamos dizer", prossegue, "que certos objetos transicionais são mais autísticos do que outros"' (Tustin, [1972] 1977, p. $70)$.

A máquina de Grandin é, ao mesmo tempo, um objeto autístico e um objeto transicional? Sabemos que sua estabilização se fez, segundo ela, graças à construção de uma máquina que teria a capacidade de moderar a hiperatividade de seu sistema nervoso. A maior parte dos clínicos a quem contou isso se preocupou com o fenômeno, alguns buscando até mesmo separála de seu objeto, considerando essa máquina nociva. Ora, sua mãe não adotou a mesma atitude. Escreveu a sua filha, estudante na época: "Não se preocupe

\footnotetext{
N. T.: no original: "machine-auto".

N. T.: no original: "la trappe à serrer". Temple Grandin a nomeia "máquina de espremer" e diz "Tem gente que a chama de minha máquina do abraço”. Sacks, O. Um antropólogo em Marte. São Paulo: Companhia de Bolso, 2008, p. 263.

6 N. T.: no original: “toute élaboration interne”. Lemay M. L'autisme aujourd'hui. O. Jacob. Paris, 2004, p. 93.

N. T.: no original: “il ne faut pas oublier, ajoute-t-elle, qu'ils se fondent parfois l'un dans l'autre. Nous pourrions dire, poursuit-elle, que certains objets transitionnels sont plus autistiques que d'autres". Tustin F. Autisme et psychose de l'enfant (1972). Paris: Seuil, 1977, p. 70.
} 
com a calha do gado'. É um 'doudou'?. Você se lembra de que rejeitava todos os 'doudous' quando era pequena? Você não os suportava"10 (Grandin, [1986] 1994, p. 136). Essa indicação parece situar muito bem, ao mesmo tempo, a proximidade e a diferença entre objeto autístico e objeto transicional: eles têm certamente alguns pontos em comum, é possível confundir um com o outro, mas, ao mesmo tempo, um observador atento, como a mãe de Grandin, nota que é precisamente característico da criança autista não ter tido um objeto transicional. Em sua infância, Temple Grandin não tinha um "doudou”, mas tinha fixações em objetos que giravam, podia sentar-se durante horas em uma praia, fazendo deslizar areia entre seus dedos e modelando montanhas minúsculas (Grandin, [1986] 1994, p. 38).

Contrariamente à tese de Tustin, sustentaremos aqui que o objeto autístico e o objeto transicional não podem se fundir um no outro, pois são radicalmente distintos. Existem, primeiro, diferenças evidentes: a persistência tardia do objeto autístico complexo, a relação transitivista do sujeito com ele e, sobretudo, o fato de que é uma criação do sujeito e não um objeto já existente, encontrado no entorno imediato. Entretanto, há algumas exceções em relação a essas diferenças. Certos objetos transicionais persistem tardiamente, mas existem objetos autísticos complexos que são adotados e não criados pelo sujeito, por exemplo, a máquina de lavar ou a televisão. Não nos deteremos sobre tais diferenças: no nível dos fenômenos, a distinção desses objetos só tem importância se suas funções não se confundem em termos da economia subjetiva. Ora, ainda aqui a diferença entre eles fica escamoteada por aquilo que têm em comum: um e outro são sedativos, acalmam o sujeito, que reage vivamente quando são retirados. Em revanche, o objeto transicional é usado para moderar a perda, nunca para estimular um sujeito, pois a criança dotada de um objeto transicional já é um sujeito desejante: seu objeto fálico, seu primeiro tesouro, demonstra uma simbolização da perda que comanda a libidinização ${ }^{11}$. O surgimento do objeto transicional mostra que uma regulação das pulsões se efetuou. Não é o mesmo que o sujeito que carrega um objeto autístico simples, que se percebe simplesmente como um objeto no mundo dos objetos, mostrando que se sente inanimado, o que revela um não funcionamento da dinâmica pulsional. Com base nisso, a clínica do autismo

\footnotetext{
N. T.: no original: "la trappe à bétail".

9 N. T.: "Doudou" é a designação dos pequenos objetos dos quais as crianças são inseparáveis: paninhos, bichinhos, fraldas, etc. Em suma, aquilo que Winnicott chamou de objeto transicional.

${ }^{10}$ N. T.: no original: "Ne t'inquiète pas de la trappe à bétail. C'est un 'doudou'. Te souviens-tu que tu repoussais tous les 'doudous' quand tu étais petite? Tu ne les supportais pás”. Grandin T. Ma vie d'autiste. [1986] O. Jacob. Paris, 1994, p. 136.

${ }^{11}$ N. T.: no original: "l'animation libidinale", que remete à uma vivificação pela libido.
} 
mostra, claramente, que cada pulsão pode se mostrar desregulada nesses casos: tal criança teme perder uma parte de seu corpo ao defecar quando o objeto da pulsão anal está presente demais; outra sofre de graves transtornos alimentares, pois a perda não foi assumida no campo da oralidade; muitos evitam qualquer contato com o objeto da pulsão escópica, fugindo do olhar do outro ou não olhando para o mundo, enquanto que a maior parte dessas crianças se mostra incapaz de fazer com que a voz sirva à troca ${ }^{8}$, permanecendo mudos, ecolálicos ou verbosos. Tudo indica que a função maior do objeto autístico complexo consiste em aparelhar um gozo pulsional em excesso. Por conseguinte, trata-se de um objeto cuja falicização é falha, ligado à pulsão de morte distintamente do que se passa com o objeto transicional.

A comparação entre o Fort-Da freudiano e os comportamentos on-off do autista ilustra claramente dois modos bem diferenciados da relação ao objeto do gozo e aponta maneiras muito específicas de tratamento deste. $\mathrm{O}$ carretel do Fort-Da, indica Lacan, é um objeto transicional. Lembremos que Freud observou com interesse o jogo de uma criança de um ano e meio bem comportada, cujo caráter gentil era louvado por todos. Essa criança, como muitas de sua idade, havia adquirido o hábito de jogar bem longe todos os pequenos objetos que lhe caíam nas mãos, pronunciando um som que os mais íntimos interpretavam como o significante "Fort" (longe). "Eu percebi, finalmente", escreve Freud, "que havia ali um jogo e que a criança só utilizava seus brinquedos para 'jogá-los longe'. Um dia”, continua, "fiz uma observação que confirmou meu modo de ver. A criança tinha um carretel de madeira enrolado em um barbante". Em sua cama, ladeada por uma cortina, embaixo da qual o carretel desaparecia, divertia-se, lançando-o e dizendo "Fort"; fazia-o reaparecer, então, saudando-o com um alegre " $\mathrm{Da}$ ' (Ei-lo). Esse era o jogo completo", continua Freud, "comportando um desaparecimento e um reaparecimento, mas do qual só se via o primeiro ato, que era incansavelmente repetido, se bem que tenha ficado evidente que o segundo ato era o que dava mais prazer à criança. A interpretação do jogo foi fácil, então. O grande esforço que a criança se obrigava a fazer tinha a significação de uma renúncia a uma tendência (à satisfação de uma tendência) e lhe permitia suportar, sem protestos, a partida e a ausência da mãe. A criança se consolava, por assim dizer, dessa partida e dessa ausência, reproduzindo a cena do desaparecimento e do reaparecimento com os objetos que tinha à mão" (Freud, [1920] 1975, p. 16-17). O carretel, aqui, tem a função de objeto transicional, que consiste em moderar a perda do objeto de gozo. Ora, é preciso assinalar que seu desaparecimento encontra-se enquadrado pela expressão de dois significantes, o

${ }^{12}$ N. T.: no original: "à l'échange”, no sentido de uma troca com o outro, o estabelecimento de vínculos. 
primeiro nomeia a ausência, o segundo acompanha o retorno da presença do objeto substitutivo. Entre os dois, dá-se uma encenação da perda. Um dos benefícios desse jogo, segundo Freud, reside na posição ativa tomada pelo sujeito em relação ao evento desagradável, permitindo-lhe satisfazer uma tendência à dominação. A manipulação do objeto transicional se acompanha, então, de uma posição ativa do sujeito, enquanto que este último, uma criança a quem se louva, precisamente, "o caráter gentil", não apresenta maiores transtornos; pode-se deduzir daí um funcionamento regulado da dinâmica pulsional.

Certos comportamentos on-off do autista podem se aproximar do jogo do Fort$D a$, como o de uma criança de 6 anos, Arnold, cujo gozo oral não está regulado e para quem todos os objetos parecem comestíveis. Ele dispõe de um objeto autístico simples, um barbante agitado diante de seus olhos. Sua terapeuta, G. Guillas, observa que ele tenta, por vezes, dosar sua oralidade desenfreada recorrendo a um livro. "Ele pega o 'Livro das estaçóes do ano', relata ela, selecionando as imagens que se relacionam com a comida, bate levemente em cada imagem, a nomeia e depois a submete aos dois tempos da presença e da ausência: 'morangos'/ 'não tem mais morangos'; 'batatas'/ 'não tem mais batatas'; 'ameixas'/ 'não tem mais ameixas'; e continua, metonimicamente: 'lanche'/ 'não tem mais lanche'; 'os biscoitos recheados'/ 'acabou, amanhã, os biscoitos recheados'; 'o chocolate'/ 'não tem mais chocolate, acabou'; 'os biscoitos'/ 'não tem mais'; 'as batatas fritas'/ 'não tem mais batatas fritas'." Em outras sessões, Arnold mobiliza de novo a oposição mais menos, conectada às imagens e endereçada a sua terapeuta, não mais somente para tratar o gozo oral, mas de um modo mais geral, aparentemente, para produzir um ordenamento do mundo. Ele se lança sobre seu livro preferido, faz com que a analista se sente, e diz "leia". "Então, página por página, seleciona imagens que são privilegiadas para ele, detém-se em cada uma delas e a submete ao tratamento habitual. Temos, então, longas séries que se declinam como se segue:

'Os morangos, até logo morangos, não há mais.

Boneco de neve, até logo, não há mais.

A sopa, não está, depois, não há mais.

Menino, até logo, não está, não há mais.

Uvas, não há mais, até logo', etc.

Todas as séries se organizam segundo esse 'há'/ 'não há mais'."

A terapeuta nota que, nessas construções, Arnold testemunha algo importante para ele (Guillas, 1999, p. 197-199). Os comportamentos on-off e o Fort-Da parecem duas maneiras para tratar a negatividade da linguagem e a dor da perda de objeto; mas uma trabalha com o signo e outra com o significante. É preciso sublinhar que as oposições reguladas de Arnold tentam 
fazer advir a perda controlada de um objeto por demais presente, graças a uma tentativa de simbolização desta. Entretanto, longe de designar a perda, a primeira expressão, em geral "há" se opõe ao "Fort", sublinhando a presença do objeto, não seu distanciamento; enquanto a segunda expressão, "não há", não saúda seu retorno, mas, ao contrário, sua colocação a distância. Em conformidade com a natureza do signo, que não apaga o objeto que representa, mas, ao contrário, relaciona-se estreitamente com ele, Arnold começa por uma nominação que opera uma conexão enlaçando uma palavra a uma imagem. Em um segundo tempo, para controlar a perda, opera de novo sobre o signo, afetando-o com uma negação: "Até logo, não está, não tem mais". Bem diferente é a relação à linguagem do sujeito que sabe manejar o Fort-Da: ele começa por nomear não uma presença, mas uma ausência, em conformidade com a natureza do significante, que apaga a coisa designada, enquanto em um segundo tempo, intervém, não o mesmo signo, mas um outro significante, o " $D a$ ", pois faz parte da natureza do significante funcionar por pares de oposições, além disso, esse segundo significante faz com que a coisa designada retorne, sempre sem nomeá-la. Só o significante realiza plenamente o assassinato da coisa; o signo continua portando a coisa, mesmo quando nega a sua presença. A partir disso, os comportamentos on-off demonstram um funcionamento que se opóe, em todos os pontos, ao Fort-Da transicional.

Entre a nominação do objeto e sua negação operada pelo sujeito autista, produz-se o toque compulsivo no objeto, que busca apagá-lo e não a fazê-lo retornar. Todos os clínicos notaram a frequência do uso do recurso do toque compulsivo ${ }^{13}$ nas crianças autistas, que dá a elas um sentimento de segurança e demonstra um controle do objeto. Esse recurso parece se valer, ativamente, da lógica do signo, assegurando a presença do objeto, em primeiro lugar, e depois afetando o mesmo com uma certa negatividade, sem, todavia, proceder a uma assunção de sua perda. Essas condutas intervêm, entretanto, para enquadrar simbolicamente o objeto que, depois disso, pode encontrar um lugar no mundo protegido das crianças autistas ali onde convém, a saber, na borda.

No que tange o tratamento do objeto de gozo, o objeto autístico complexo inscreve-se em uma lógica semelhante: esforça-se por enquadrar seu excesso de presença e colocá-lo a distância, a fim de produzir uma ativação precária da dinâmica pulsional, permitindo instaurar uma certa animação subjetiva. Um objeto autístico simples, como mostrou Tustin, proporciona, primeiro, um gozo autossensual que faz barreira ao mundo externo, mas é, também, um

\footnotetext{
${ }^{13}$ N. T.: no original: "conduites de tapotement".
} 
duplo "vivo", portador de um retorno de gozo sobre a borda; caso se articule ao Outro de síntese ${ }^{15}$ e participe de uma pequena ilha de competência ${ }^{11}$, se torna um objeto autístico complexo cujas ramificações conseguem, por vezes, estender-se até o campo social. O objeto autístico simples permanece grudado no sujeito, está a serviço de uma autossensualidade que o isola; enquanto que o objeto autístico complexo afasta o gozo do corpo do sujeito para localizálo em uma borda, que não é mais somente barreira ao Outro, mas também conexão à realidade social.

\section{Os objetos autísticos complexos de Joey}

Os objetos autísticos complexos mais conhecidos e estudados são, certamente, os da criança-máquina, célebres a partir do relato de seu percurso terapêutico, feito por Bettelheim em 1967, em "La forteresse vide" (Bettelheim, [1967] 1969).

Atualmente, é de bom tom denegrir as pesquisas de Bettelheim, sobretudo em função da culpabilização dos pais, considerados responsáveis pelo autismo dos filhos. Sua posição era, seguramente, mais branda, posto que afirmava que não era a atitude da mãe que produzia o autismo, mas a reação espontânea da criança a essa atitude (Bettelheim, [1967] 1969, p. 102). Apesar de todas as críticas, não devemos esquecer que ele foi um dos primeiros, ainda nos anos 50, a demonstrar que o diagnóstico do autismo não deveria levar à desesperança terapêutica. Preconizando métodos educativos orientados por noções psicanalíticas, obteve resultados no tratamento do autismo na Escola Ortogênica de Chicago (Bettelheim, [1967] 1969, p. 507 $508)^{16}$. Mesmo que tivesse somente nos legado o relatório sobre o tratamento de Joey, qualquer clínico interessado no funcionamento autístico deveria, hoje, render-lhe homenagens. Desde sua chegada à Escola ortogênica, Joey se apresenta como uma criança-máquina, não podendo separar-se de suas lâmpadas e de seu pesado motor. O mundo se dividia, segundo ele, entre "as pessoas vivas" e "as pessoas que precisam de lâmpadas", do que se deduz que

\footnotetext{
${ }^{14}$ N. T.: no original: "l’Autre de synthèse".

${ }^{15}$ N. T.: no original: "un îlot de compétence".

16 “O resultado final do tratamento é 'ruim' em oito de quarenta de nossas crianças", escreve Bettelheim, "pois eles não conseguiram, apesar da melhora, um mínimo de adaptação social necessária à vida em sociedade. O resultado é 'médio' em quinze crianças e 'bom' em dezessete. Assim, Eisenberg só consegue 5\% de resultados bons, enquanto que nosso trabalho demonstra que um tratamento intensivo pode elevar esse número a 42\% [...] Cinco em dezessete diplomaram-se em universidades e, entre eles, três obtiveram diplomas superiores" (Bettelheim B. La forteresse vide, o.c., p. 507-508). Tais resultados, que parecem muito excepcionais, levaram alguns a contestar o diagnóstico de autismo no que concerne esses sujeitos. O que nós sabemos hoje sobre o autismo os torna, ao contrário, completamente plausíveis: os resultados obtidos anos atrás em Viena por Asperger, com a ajuda de métodos educativos, não conhecidos naquela época, foram, entretanto, do mesmo tipo.
} 
estas últimas carecem do sentimento de vida. Somente as máquinas, através da corrente elétrica que comunicam, podem insuflar neles temporariamente esse sentimento. Joey as havia concebido antes de sua chegada a Chicago. Desde seus 6 anos de idade, máquinas assim devem ser mobilizadas para que ele possa lidar com o objeto da pulsão oral. Para comer, relata Bettelheim, Joey tinha que se ligar a um circuito elétrico. "Grudado na mesa, deveria ficar sentado em um pedaço de papel, e suas roupas tinham que ser cobertas por guardanapos de papel. Se não, nos diz ele mais tarde, não haveria isolação e a corrente o deixaria. Dito de outro modo, se a corrente que dava a vida e se nenhuma energia se derramassem em seu corpo, como poderia ele comer? Não podia beber sem a ajuda de um complicado sistema de canos construído com canudinhos. Os líquidos deveriam ser bombeados dentro dele (ou ao menos ele tinha essa impressão). Não podia, então, se permitir chupar" (Bettelheim, [1967] 1969, p. 314). ${ }^{17}$ Notemos o quanto substiste, aí, um sentimento de inércia de sua parte: toda energia lhe parece vir do objeto.

Em um primeiro tempo, as máquinas destinam-se ao tratamento do objeto oral, em seguida, a vocação primordial delas é, claramente, regular um objeto anal invasor. "Antes de sua chegada à Escola", nota Bettelheim, "a maior parte das 'prevençōes' de Joey diziam respeito à ingestão, à aquisição da energia vital. É somente mais tarde que a analidade começa a se instalar abertamente. Primeiro, pela eliminação nos cestos de papel, depois pelo dilúvio de diarreia que inundou o mundo inteiro." Fica claro que a regulação do objeto anal constitui uma tarefa prioritária dos objetos autísticos complexos de Joey. Entretanto, a máquina à qual se referia no início de sua estadia servia também, mesmo que de maneira mais discreta, a tratar o objeto escópico, posto que era composta de numerosas lâmpadas, graças às quais ele podia acender ou apagar a luz. Comportava, além disso, um alto-falante que aparecia em uma foto da máquina (Bettelheim, [1967] 1969, Documents. Joey. Figure 11) ${ }^{18}$. Aparentemente, ela permitia a Joey falar e ouvir. De fato, tinha, sobretudo, a função de introduzir o corte para regular o gozo vocal: ele afirmava, com efeito, "que só podia ouvir com as máquinas porque poderia pará-las se fosse

\footnotetext{
${ }^{17}$ N. T.: no original: "Collé contre la table, il devait être assis sur un morceau de papier et ses vêtements devaient être couverts de serviettes en papier. Sinon, nous dit-il plus tard, il n'était pas isolé et le courant le quitterait. Autrement dit, si le courant qui donnait la vie et si aucune énergie ne coulait dans son corps, comment pourrait-il manger? Il ne pouvait pas boire sans l'aide d'un système compliqué de tuyauterie construit avec des pailles. Les liquides devaient être pompés dans lui (ou du moins avait-il cette impression). Il ne pouvait donc pas se permettre de sucer”. Ibid., p. 314.

${ }^{18}$ N. T.: no original: “Avant son arrivée à l'Ecole, note Bettelheim, la plupart des 'préventions' de Joey concernaient l'ingestion, l'acquisition d'énergie vitale. C'est seulement plus tard que l'analité commença à s'installer ouvertement, d'abord par l'élimination dans les corbeilles à papier, puis par le déluge de diarrhée qui inonda le monde entier". Il est manifeste que la régulation de l'objet anal constitue une tâche prioritaire des objets autistiques complexes de Joey. Toutefois, la machine à laquelle il se référait au début de son séjour servait aussi, quoique de manière plus discrète, à traiter l'objet scopique, puisqu'elle se composait de nombreuses lampes, grâce auxquelles il pouvait allumer ou couper la lumière. Elle comportait de surcroît un haut-parleur, qui apparaît sur une photo de la machine. Ibid. In: Documents. Joey. Figure 11.
} 
necessário" (Bettelheim, [1967] 1969, p. 395) ${ }^{19}$.

A criança autista dispõe de um saber que, todavia, nunca aprendeu, com respeito à energia vital que lhe falta. Joey sabia que esta provinha de um objeto e que este tirava seus poderes de uma perda corporal. A abordagem de tal perda é tão angustiante que ele organizou uma defesa radical para se proteger dela: a recusa do apelo ao Outro, que faz obstáculo à assunção da alienação na linguagem. Joey gritava "Explosão" no momento em que o material fecal deixava seu corpo, como se ali se tratasse, comenta Bettelheim, de evento ao mesmo tempo grandioso e devastador. Seus efeitos quase cósmicos eram inferidos de afirmações como: "Estou ligando minha lâmpada; vou acender as lâmpadas externas" (Bettelheim, [1967] 1969, p. 340) ${ }^{20}$. Outras numerosas anotações indicam que, segundo Joey, o objeto anal produz energia. Muitos de seus desenhos e pinturas mostram a origem da luz, do fogo e de enormes explosões em material fecal iluminado por uma luz ou iluminadas por um cigarro. A escolha do objeto autístico sucessor da automáquina, a saber, uma criança da instituição, de nome Ken, é operada quando Joey o vê tratar o objeto anal. "Aconteceu algo hoje, relata ele. Eu vi uma das pequenas pessoas ${ }^{21}$ na privada. Eu sabia o nome dessa pequena pessoa. Eu dei uma olhadinha por baixo da porta. Durante o tempo em que havia fezes, houve uma grande claridade e uma explosão" (Bettelheim, [1967] 1969, p. 377)22. Nesse período, qualquer apreensão de perda de um objeto de gozo é vivida por Joey como uma castração real. Ele precisava segurar seu pênis quando defecava e tampar seu ânus quando urinava. Terrificava-o o fato de que algo abandonasse seu corpo. Entretanto, seus intestinos funcionavam porque considerava que eles eram movidos por máquinas. Quando tinha fezes duras, anunciava que "precisava de máquinas melhores, para esquentar suas fezes com intuito de amolecê-las para dar-lhes uma consistência normal".

Os objetos autísticos complexos de Joey tentam regular o gozo para fornecer-lhe uma energia vital. Ligar-se a eles o anima, desligar-se deles o deixa sem vida. Nos primeiros tempos de sua estada na Escola Ortogênica, ele parecia funcionar guiado por um controle remoto, como um "homem mecânico" movido por máquinas que havia criado e tinham escapado a seu controle. "Havia momentos, por exemplo", relata Bettelheim, "nos quais um

\footnotetext{
19 N. T.: no original: "qu'il ne pouvait entendre qu’avec des machines parce qu'il pouvait les arrêter si besoin était". Ibid., p. 395.

${ }^{20}$ N. T.: no original: “Je branche ma lampe; je vais allumer les lumières extérieures”. Ibid., p. 340.

${ }^{21}$ N. T.: no original: "petites personnes”, designação não usual na língua francesa.

${ }^{22}$ N. T.: no original: "Il est arrivé quelque chose aujourd'hui, rapporte-t-il. J'ai vu une des petites personnes aux cabinets. Je savais le nom de cette petite personne. J'ai jeté un coup d'œil sous la porte. Pendant qu'il avait une selle il y a eu une grande lueur et une explosion”. Ibid., p. 377.
} 
longo período de não existência era interrompido pela ativação da máquina e a passagem a um regime cada vez mais elevado, até que o desenlace fosse atingido em uma 'explosão' pulverizadora. Isso se produzia várias vezes ao dia e terminava quando Joey jogava brutalmente uma ampola de rádio ou uma lâmpada, que se desfazia em mil pedaços com um ruído de explosão. [...] Quando chegava a hora de fazer o mundo explodir, essa criança, que vivia muda e sem se mexer, na maior calma, de repente, corria por todo lado e gritava 'Crack! Crack!' ou 'Explosão!', lançando uma lâmpada ou um motor. Assim que o objeto lançado quebrava e que o ruído se apagava, Joey se apagava também. Sem nenhuma transição, voltava à sua não existência. Depois que a máquina explodia, ele não tinha mais movimento, vida, mais nada" (Bettelheim, [1967] 1969, p. 302 e 304) ${ }^{23}$.

Apesar de ter o poder de animar o sujeito, a automáquina não dá muita segurança, pois tem também uma capacidade de autodestruição. Bettelheim a qualifica por vezes de "monstro" ou de "máquina infernal". As primeiras máquinas de Joey são amedrontadoras: "Podíamos adivinhar os perigos que essas máquinas representavam, com base nos nomes que ele dava a elas, tais como 'quebradora de crânios"' (Bettelheim, [1967] 1969, p. 324) ${ }^{24}$. Nisso, os objetos autísticos complexos são bem diferentes dos objetos transicionais. Estes últimos são objetos fálicos asseguradores, enquanto os outros, às voltas com o real e com a pulsão de morte, são inquietantes por vezes. O que melhor atesta isso é a vontade de numerosos terapeutas de fazê-los desaparecer. Entretanto, considerando que a principal função do objeto autístico complexo consiste em tratar o gozo que retorna sobre a borda, é em suas formas mais elaboradas que ele consegue maior sucesso nisso, de modo que o incômodo que suscita tende a se atenuar.

As "explosões" de Joey esclarecem o que muitos clínicos constatam: as palavras mais frequentemente pronunciadas pelas crianças autistas são "quebrado" ou "rachado" (Lemay, 2004, p. 159). O sistema elétrico no qual Joey se imagina o situa em uma dependência inquietante de um Outro todopoderoso, como atesta o fato de a máquina estar sempre mais ou menos

\footnotetext{
${ }^{23}$ N. T.: no original: "Il y avait des moments, par exemple, relate Bettelheim, où une longue période de non-existence était interrompue par la mise en route de la machine et de son passage à un régime toujours plus élevé, jusqu’à ce que le dénouement soit atteint dans une 'explosion' pulvérisatrice. Cela se produisait plusieurs fois par jour et se terminait lorsque Joey projetait brutalement une lampe de radio ou une ampoule électrique qui éclatait en mille morceaux dans un bruit d'explosion.[...] Dès qu'était arrivée l'heure de faire exploser le monde, cet enfant qui vivait muet et sans bouger, dans le plus grand calme, brutalement devenait complètement fou, courait dans tous les sens et criait 'Crack! Crack!' ou 'Explosion!' en lançant une ampoule ou un moteur. Dès que l'objet lancé s'était brisé et que le bruit s'éteignait, Joey s'éteignait aussi. Sans transition aucune, il retournait à sa non-existence. Dès que la machine avait explosé, il n'y avait plus de mouvement, plus de vie, plus rien”. Bettelheim B. La forteresse vide. Gallimard. [1967]. Paris. 1969, p. 302; 304.

${ }^{24}$ N. T.: no original: "on pouvait deviner les dangers que représentaient ces machines d'après les noms qu'il leur donnait, tels que 'casseur de crânes”. Ibid., p. 324.
} 
desregulada; o único meio do qual dispõe para se separar desse Outro provoca o abandono de seu ser. Sua tentativa de romper uma continuidade entre o sujeito e sua borda leva-o a um corte real catastrófico. A criança autista é invadida por um objeto de gozo que se esforça por tratar, seja dominando-o, seja separando-se dele. Entretanto, essa separação, como relata Joey, no que concerne à defecação e à micção, é vivida como uma castração real, como se uma parte do corpo fosse arrancada. A voz e o olhar recebem, por vezes, o mesmo tratamento: "Primeiro", conta Joey, "você coloca cera nos ouvidos. Isso o protege e entope suas orelhas, de modo que você não escuta as coisas que não quer ouvir. Você acrescenta cera e ainda mais cera, para estar certo de não ouvir ; isso o deixa surdo. A surdez se alastra tanto, que todo mundo fica surdo e ninguém pode ouvir. Ela se estende à cegueira. Então as pessoas ficam surdas e cegas" (Bettelheim, [1967] 1969, p. 396) ${ }^{25}$. Sabe-se, além disso, que tais crianças têm uma propensão a condutas automutilatórias. No início de sua estada, quando Joey era contrariado, ficava terrivelmente colérico "e tentava enfiar um lápis em sua mão". Nesse tempo, a única maneira que tinha de reagir aos incidentes consistia em destruir ou punir uma parte de seu corpo (Bettelheim, [1967] 1969, p. 404). Entretanto, a complexificação dos objetos autísticos, pela localização do gozo sobre uma borda na qual comparece, atenua o poder de malvadeza do Outro real, de modo que esses objetos moderam e, depois, fazem cessar as condutas automutilatórias. "Dos motores e das lâmpadas", constata Bettelheim, "Joey tirava daí a força afetiva necessária para interromper suas iniciativas de autodestruição" (Bettelheim, [1967] 1969, p. 334) ${ }^{26}$.

Não é somente porque seus objetos autísticos complexos o acalmam que o sujeito demonstra tanta solicitude a respeito deles, mas também porque tem a intuição que, se os aperfeiçoar, poderá obter ainda mais deles. Seguindo, passo a passo, o relato do percurso de Joey na Escola Ortogênica, constatamos que ele encontra soluçôes cada vez mais eficazes para moderar sua angústia e construir seu mundo. E que essas soluções se apoiam em uma sucessão de objetos cujas características se modificam. Após ter sido, muito cedo, cativado pelos ventiladores, apresenta-se a Bettelheim como uma "criançamáquina”, depois, liga-se a um menino da Escola, Ken, que chama de Kenrad em referência a mais potente das lâmpadas. A percepção que Joey tem dele

\footnotetext{
${ }^{25}$ N. T.: no original: "D'abord, rapporte Joey, vous vous mettez de la cire dans les oreilles. Ça vous protège et ça vous bouche les oreilles de sorte que vous n'entendez pas les choses que vous ne voulez pas entendre. Vous ajoutez de la cire et encore de la cire pour être bien sûr de ne pas entendre ; ça vous rend sourd. La surdité se répand tellement que tout le monde est sourd et personne ne peut entendre. Elle s'étend à la cécité. Alors les gens sont sourds et aveugles”. Ibid., p. 396.

${ }^{26}$ N. T. No original: "Des moteurs et des lampes, constate Bettelheim, Joey tirait la force affective nécessaire pour interrompre ses entreprises d'auto-destruction”. Ibid., p. 334.
} 
mesmo se humaniza progressivamente, como demonstram as representações que faz de si mesmo em desenhos, em papoose ${ }^{27}$, primeiro elétrico, depois cada vez mais humano. Em seguida, vem um novo objeto complexo, encarnado em outro menino da Escola, Mitchell, o mais normal entre eles, segundo Bettelheim. Esse objeto não é mais uma lâmpada. Joey cria para Mitchell e para si mesmo uma família, a família "Carr". Quando Mitchell deixa a Escola, isso o afeta muito, de modo que se coloca novamente sob o controle das máquinas. Constatamos que o trabalho defensivo é longo e difícil, com avanços e recuos: os objetos autísticos de Joey apresentam-se em nítida progressão, uns em relação aos outros. Entretanto alguns são contemporâneos em seu percurso: por exemplo, a automáquina, Kenrad e Mitchell. Não é assim para o último deles, um companheiro imaginário denominado Valvus, um menino como Joey. A construção dele faz com que as máquinas desapareçam, pouco a pouco, enquanto Kenrad et Mitchell são esquecidos. Mais tarde, após terminar os estudos secundários em uma escola técnica, especializando-se em eletrônica, Joey volta à Escola Ortogênica, levando uma máquina elétrica que tinha construído, uma válvula cuja função é mudar a corrente alternativa em corrente contínua, quer dizer, uma máquina capaz de regular a energia elétrica, aquilo do qual, exatamente, imaginava precisar quando chegou à Escola.

Retomemos um pouco mais detalhadamente a evolução dos objetos de Joey: o que ele nos ensina sobre a função deles? A relação transitivista mantida com seus objetos autísticos confirma, por um lado, a ênfase dada por Tustin ao fato de que o sujeito busca incorporar suas qualidades. Ser ou parecer uma máquina traz vantagens para Joey: "As máquinas são bem melhores que o corpo", afirma ele. "Elas não quebram. São muito mais duras e sólidas" (Bettelheim, [1967] 1969, p. 343) ${ }^{28}$. Ora, o que é verdadeiro para o objeto máquina o é menos quando esse é encarnado por um semelhante e menos ainda quando o objeto se torna um companheiro imaginário. Se há uma qualidade comum a todos esses objetos, qualidade que Joey tenta adquirir, ela é, claramente, a capacidade deles para regular a energia vital. Ele os utiliza para tratar sua afetividade. Eles são "captadores" de libido, reguladores de gozo, traduzem um trabalho subjetivo de tratamento das pulsões. É sua função dinâmica, negligenciada por Tustin.

Com sua máquina, Joey encontrava-se em uma relação fusional, de modo que só podia tratar a energia vital elétrica com um corte que provocava

${ }^{27}$ N. T.: "Papoose": bebê, para alguns indígenas da América do Norte.

${ }^{28}$ N. T.: no original: "Les machines sont bien mieux que le corps, affirma-t-il. Elles ne cassent pas. Elles sont beaucoup plus dures et plus solides". Ibid., p. 343. 
efeitos de abandono que o concerniam. Correlativamente a isso, a defecação mobilizava as fantasias de perda de partes do corpo. Com Kenrad, operase um progresso: ele é, essencialmente, uma máquina para tratar o material fecal, daí o qualificativo de menino-lâmpada que Bettelheim lhe dá. Trata-se certamente de um ser humano, mas pertence ainda ao gênero das máquinas. Com Kenrad, o objeto anal é colocado à distância: não são mais máquinas pouco diferenciadas do sujeito que devem se encarregar disso. Joey não se interessa, de modo algum, ao que Ken faz ou pensa, sua preocupação central é bombear o material fecal fora dele. "Cada vez que Joey se aproximava por trás ou que Ken virava de costas para ele", escreve Bettelheim, "era preciso que ele o fizesse ir para a privada [...] Joey se mantinha o mais próximo possível das nádegas de Ken, ou o quão próximo Ken permitisse, perfurando, bombeando e extraindo com gestos, recuando, depois, como se tirasse matéria fecal. Aqui também, a pantomima era tão boa que o observador poderia se enganar. Joey não conseguia compreender que alguém pudesse defecar 'sozinho'. Somente uma máquina poderia fazê-lo" (Bettelheim, [1967] 1969, p. 379) ${ }^{29}$. Ora, essa capitalização do objeto de gozo energético em Kenrad trazia inconvenientes, pois esse se torna, por isso, onipotente e perigoso. Seria capaz de mutilar ou de matar, até mesmo de destruir a escola e, talvez, o mundo inteiro. "Enquanto os poderes de Kenrad aumentavam", nota Bettelheim, "Joey ia se tornando nulo" (Bettelheim, [1967] 1969, p. 379)..$^{30}$ Diante desse Outro todo-poderoso, Joey corria o risco de cair na posição de satisfazer, supostamente, a vontade de gozo desse Outro, a do objeto caído.

Entretanto seus esforços para sair de sua solidão autística, sustentados pelos educadores da Escola Ortogênica, permitem-lhe ousar brincar de "papoose", termo que designa o bebê para alguns indígenas da América do Norte. Ele produz, então, inumeráveis desenhos dele mesmo como papoose. Primeiro, ligado a uma eletricidade sem fio e movido por máquinas; depois, no interior de um abrigo de vidro. A ligação com Kenrad parece ter contribuído para a incorporação de uma certa humanidade: Joey não se percebe mais como uma máquina, mas como uma pessoa. Mas o papoose deve contribuir, como sempre, ao tratamento do material fecal.

Joey sonha, então, com um menino mais velho, que tinha uma atitude de

\footnotetext{
${ }^{29}$ N. T.: no original: "Chaque fois que Joey s'approchait par derrière ou que Ken lui tournait le dos, écrit Bettelheim, il lui fallait le faire aller à la selle [...] Joey se tenait aussi près que possible des fesses de Ken, ou aussi près que Ken le permettait, forant, pompant et extrayant par gestes, puis se reculant, comme s'il tirait des matières fécales. Ici aussi, la pantomime était si bonne que l'observateur aurait pu s'y tromper. Il était au-dessus des moyens de Joey de comprendre que quelqu'un pût aller à la selle 'par ses propres moyens'. Seule une machine pouvait le faire”. Ibid., p. 379.

${ }^{30}$ N. T.: no original: "Au fur et à mesure que les pouvoirs de Kenrad augmentaient, note Bettelheim, Joey devenait davantage un bon à rien”. Ibid., p. 379
} 
proteção para com ele e deveria em breve deixar a Escola, Mitchell. "Eu estava no banheiro dos meninos com Mitchell. Ele estava sentado na privada", relata Joey, "ia defecar, e eu estava ajoelhado diante dele" (Bettelheim, [1967] 1969, p. 384) ${ }^{31}$. Mitchell capitaliza, também, o gozo, mas o domina melhor: Joey não imagina que sua defecação produza explosões e luzes. Desde então, Joey divide os poderes: os bons se ligam a Mitchell, e os maus a Kenrad. Entretanto, torna-se, agora, dependente da energia anal de Mitchell. "Quando Mitchell rejeitava Joey porque ele se interessava por sua eliminação, a reação de Joey era: 'Ele quebrou meus sentimentos'" (Bettelheim, [1967] 1969, p. 388) ${ }^{32}$. Prossegue, entretanto, sua humanização, incorporando certas características de Mitchell, que tenta imitar, cada vez mais. Este último, escreve Bettelheim, foi a primeira pessoa da qual ele tirou um pouco de força (sempre sob a forma de energia elétrica) tocando alguns objetos que lhe davam energia, seu copo, seu prato ou qualquer outro objeto que servisse para sua alimentação. Suas relações com a alimentação e com a defecação melhoram ao mesmo tempo. Também, quando Mitchell deixa a Escola, Joey se sente atingido em seu ser e deve, de novo, apelar para suas máquinas para tratar o gozo: "Naquele dia", relata Bettelheim, "ele foi para a cama dizendo: 'Tenho uma pneumonia; Mitchell partiu' e se colocou de novo sob o controle das máquinas. Há algum tempo, ele ia ao banheiro sem assistência mecânica; agora, tinha, de novo, uma necessidade frenética da mesma para 'expulsar' as fezes". A partida de Mitchell faz fracassarem os esforços de Joey para introduzir um sistema binário de tratamento do gozo, repartido entre dois polos de onipotência, um produzindo coisas boas e outro concentrando os poderes de destruição. Essa introdução de uma bipartição nos objetos parece ter produzido uma melhor regulação da energia pulsional.

Com a partida de Mitchell, Joey deve encontrar outra solução para continuar seu trabalho de luta contra a solidão. Inventa, então, um companheiro imaginário. Este constitui uma das encarnaçōes possíveis do objeto autístico complexo. Enquanto este último se humaniza, sua dimensão de duplo do sujeito torna-se cada vez mais evidente. Bettelheim é um dos primeiros clínicos a descrever o espantoso fenômeno de um companheiro imaginário do autista. É preciso notar que Tustin não dá importância a isso. Esse fenômeno será, entretanto, fortemente confirmado, 40 anos depois do tratamento de Joey, pelo notável testemunho de Donna Williams, relatando

\footnotetext{
${ }^{31}$ N. T.: no original: "J'étais dans les cabinets des garçons avec Mitchell. Il était assis sur les cabinets, relate Joey, et il allait à la selle et j'étais agenouillé devant lui”. Ibid., p. 384.

${ }^{32}$ N. T.: no original: "Lorsque Mitchell repoussait Joey parce qu'il s'intéressait à son élimination, la réaction de Joey était: "Il a cassé mes sentiments". Ibid., p. 388.
} 
sua abertura para o mundo graças à criação de Willie e Caroll. Além disso, ela menciona ter encontrado vários autistas de alto desempenho vivendo em companhia de personagens semelhantes a seus duplos de juventude. De igual modo, apesar de mais discretamente, Temple Grandin conta sua propensão a criar companheiros imaginários (Bisban, Alfred Costello). Daniel Tammet relata diálogos, que duraram alguns meses, com uma velha mulher que o tranquilizava, chamada Anne, com mais de cem anos, que desapareceu depois de ter anunciado sua morte próxima (Tammmet, 2006, p. 99-101). Em resumo, esse objeto duplo se encontra com bastante frequência na clínica do autismo de alto desempenho.

Joey o nomeia "Valvus" e o concebe "nem todo bom nem todo malvado, nem totalmente impotente nem onipotente", de fato, idêntico a ele. Esse objeto duplo caracteriza-se por poder se regular sozinho. "Assim como uma válvula, podia se fechar ou se abrir tanto quanto fosse necessário ou conveniente". A partir do que regula ela esse movimento? Essencialmente, a partir de material fecal. Graças a Valvus, nota Bettelheim, Joey "atinge a autonomia, quer dizer, um controle pessoal de sua própria eliminação" (Bettelheim, [1967] 1969, p. $389)^{33}$. Além disso, algum tempo antes, Joey tinha inventado a família "Carr", uma boa família imaginária. Providencia para ela uma casa cuja característica principal "era de possuir um complicado sistema para o saneamento básico com um 'registro para as águas sujas" controlada por Valvus. Em resumo, este último, como observa de forma pertinente Bettelheim, forneceu a Joey "uma estrutura exteriorizada, para uma personalidade interior", com a qual ele construiu "o dispositivo de segurança do qual necessitava". Ao mesmo tempo, começa a aceitar suas emoções, enquanto abandona, pouco a pouco, o recurso das lâmpadas e da eletricidade. A invenção de Valvus foi necessária para introduzir uma regulação do gozo anal.

Em seguida, Joey desenvolveu uma fantasia de autoprocriação anal, desovando a si mesmo, imaginando seu nascimento e o de Valvus a partir de um mesmo ovo. Uma tal fantasia faz eco a seu trabalho de saída de um fechamento sobre si mesmo efetuado na solidão de uma relação que se apoiava nos objetos duplos e, prioritariamente, consagrada a tratar o gozo anal. Sua vida imaginativa e suas criaçôes verbais se enriqueceram, seus sentimentos foram mais bem integrados, ele se abriu aos outros, tanto que desejava viver de novo com sua família. Terminou, então, os estudos secundários em uma escola técnica, "tirando proveito de seu interesse persistente", nota Bettelheim, "mas

${ }^{33}$ N. T.: no original: “atteignit l'autonomie, c'est-à-dire un contrôle personnel de sa propre élimination". Ibid., p. 389. 
agora mais normal, pelas coisas técnicas" (Bettelheim, [1967] 1969, p. 407) ${ }^{34}$. Em resumo, ao sair da Escola Ortogênica, na idade de 18 anos, depois de ter passado nove anos ali, tinha abandonado a posição autística de fechamento em si mesmo. Notemos o enredamento dos componentes da borda: o objeto autístico é um duplo e seu tratamento da energia elétrica orienta Joey para estudos em eletricidade, nos quais encontra um espaço de competência ${ }^{35}$, na base do desenvolvimento de seu Outro de síntese.

Três anos após sua partida, ele volta para visitar suas educadoras e Bettelheim. Escolheu levar seu diploma de colégio e uma máquina elétrica que ele mesmo havia construído. Fez uma demonstração dela para todos os que queriam ouvi-lo: "Era uma coisa muito pesada", constata Bettelheim, "que pesava tanto quanto as lâmpadas e os motores quando de sua chegada à Escola. Mas, em sua maneira de carregar essa máquina, havia triunfo e satisfação. Tratava-se de uma válvula cuja função era mudar a corrente alternativa em corrente contínua. Ele nos mostrou em detalhes como esse dispositivo que tinha construído mudava o eterno vaivém da corrente alternativa em corrente direta e contínua” (Bettelheim, [1967] 1969, p. 418) ${ }^{36}$. Em um texto já antigo, G. e D. Miller sublinham que essa máquina, que muda a corrente alternativa em corrente contínua, "domina a eletricidade louca da qual ele era o joguete" (Miller, 1984, p. 54) ${ }^{37}$. Por isso, ela parece se inscrever corretamente na linhagem dos objetos autísticos complexos pelos quais o sujeito consegue operar uma certa regulação do gozo pulsional.

Uns trinta anos mais tarde, Joey continuava solteiro, mas levava uma vida autônoma, sustentando-se com um trabalho no ramo da eletrônica (Sutton, 1995, p. 510).

Seu testemunho enfatiza claramente a contribuição dos objetos autísticos complexos para a saída do fechamento sobre si mesmo e a socialização do sujeito autista. Certamente, eles contribuem para dar consistência à imagem do corpo, assim como protegem da angústia, mas convém sublinhar, sobretudo, seu aporte para a libidinização do sujeito. Por intermédio deles, o

\footnotetext{
${ }^{34}$ N. T.: no original: "mettant à profit son intérêt persistant, note Bettelheim, mais maintenant plus normal, pour les choses techniques". Ibid., p. 407.

35 N. T.: no original: "un îlot de compétence".

${ }^{36}$ N. T.: no original: "C'était une chose très lourde, constate Bettelheim, qui l'alourdissait maintenant autant que les lampes et les moteurs lors de son arrivée à l'Ecole. Mais dans la façon de porter cette machine, il y avait du triomphe et de la satisfaction. Il s'agissait d'un redresseur dont la fonction était de changer un courant alternatif en courant continu. Il nous montra en détail comment ce dispositif qu'il avait construit lui-même changeait l'éternel va-et-vient du courant alternatif en un courant direct et continu". Ibid., p. 418.

${ }^{37}$ N. T.: no original: "maîtrise l'électricité folle dont il était le jouet". Miller G. et D. L'enfant-machine, in Ornicar? Revue du champ freudien. 1984,31 , p. 54.
} 
gozo inquietante, desregulado, é captado, colocado à distância, dominado. As pulsões se animam a partir disso. O objeto autístico é um duplo que suplementa a falha fálica e obtura a hiância do Outro. A realidade do autista não é composta por objetos que se inscrevem sobre um fundo de falta: ele investe essencialmente o mundo e seus objetos por derivação do objeto autístico complexo. Sua relação à linguagem, que se exterioriza desde os signos, tem o mesmo funcionamento. Resumindo, para quem presta atenção à fala de Joey colhida por Bettelheim, parece evidente que a maior função do objeto autístico ultrapassa a de um duplo protetor, é patente que ele contribui à organização de uma energética pulsional.

\section{A máquina para gado ${ }^{38}$ de Temple Grandin}

Por que esse dado clínico permanece desconhecido se está claramente exposto em uma obra que nenhum especialista do autismo ignora? Seriam atípicos os transtornos de Joey? Seu tratamento não seria equivalente a nenhum outro? É preciso evitar tomá-lo como exemplo? Os autistas de Bettelheim eram verdadeiramente autistas?

A publicação, nos anos 90, de vários testemunhos excepcionais de autistas de alto desempenho, especialmente os de Donna Williams, de Birger Sellin e de Temple Grandin, permite renovar a abordagem dessas questôes. Aproximando-os do trabalho de Bettelheim, a clínica de Joey se revela exemplar, mais do que atípica. Qual a utilidade de Willie e Carol, os dois companheiros imaginários criados por Donna Williams? "São", ela afirma em 1992, "duas criaturas nascidas de minha imaginação que me ajudaram a viver independentemente e evitaram que eu acabasse em uma instituição psiquiátrica. Ajudaram-me, também, em uma viagem no curso da qual, ponto por ponto, consegui, finalmente, existir como ser dotado de sentimentos e emoções no 'mundo', no mundo real" (Williams, 1992, p. 289). Encontramos, nesses companheiros imaginários, a função principal dos objetos autísticos complexos: eles protegem da angústia, permitem investir no mundo por derivação, contribuem a uma integração dos afetos e a uma animação do sujeito, tudo isso por intermédio de um tratamento imaginário da perda. Donna Williams sublinha o quanto suas criações, apesar de socorrê-la fortemente, mobilizam ao mesmo tempo um imaginário de castração. "Pois, se Carol e Willie 'participam' do mundo", escreve ela, "o preço é uma verdadeira mutilação psíquica" (Williams, 1992,

\footnotetext{
${ }^{38}$ N. T.: no original: "La trappe à bétail”. C. f. Oliver Sacks, em seu livro Um antropólogo em Marte, op. cit., p. 267, para uma descrição da própria Temple Grandin.
} 
p. 169) ${ }^{39}$. Produzindo o doloroso rompimento ${ }^{40}$ realizado pela maior parte dos autistas, apreendido frequentemente a partir de um ligar-se e desligar-se, os objetos autísticos complexos operam um enquadramento do gozo. Para, a partir disso, chegar a uma certa regulação pulsional, é preciso encenar ${ }^{41}$ um controle da perda simbólica. Essa é extremamente explícita quando Williams realiza o assassinato de um de seus companheiros imaginários (Williams, 1992, p. 113). Ela sublinha os olhos de uma das bonecas que supostamente o representa, depois o subtrai do campo escópico ("um par de olhos verdes brilhando no escuro"), fechando-a num caixão e o imergindo em um lago, até "apagar qualquer traço do funeral". O final do tratamento de Dibs revela um procedimento semelhante, não do olhar, mas da voz. Ele se apodera de um gravador, pedindo a este para "pegar e guardar sua voz"; depois, entrega a fita a sua terapeuta: "coloque-a na caixa, diz a ela, guarde-a, guarde-a só para nós dois" (Axline, [1964], (1967), p. 199). Em uma sessão ulterior, verifica se ela guardou bem a coisa e repete o fenômeno. Em seguida, fica evidente que essa subtração do gozo vocal liberou a fala de Dibs.

A uso dinâmico dos objetos autísticos operado por Williams ou Joey não é absolutamente excepcional: Temple Grandin enfatiza mais ainda a função energética de sua extraordinária criação. Muito cedo, ela teve a intuição de que precisava construir para si mesma uma "máquina de bem-estar" para regular suas estimulaçõos excessivas. A história de sua autoterapia centra-se na construção de uma máquina. Ainda pequena, relata, "gostava de confeccionar objetos". O "desejo de construir um aparelho" surge quando ela está em CE $2^{42}$, um aparelho "que lhe traria bem-estar a partir do contato". No final de seus estudos secundários, mais ou menos levados a cabo, em uma grande solidão, entrecortada por crises de nervos, problemas de comportamento e sofrimentos físicos, ela consegue realizar "uma máquina de contenção", cuja ideia lhe surgiu observando animais amedrontados e contraídos serem aprisionados em uma máquina para gado. Constata que eles se acalmam quando as paredes se fecham docemente sobre seus flancos. A máquina que ela constrói lhe traz o mesmo apaziguamento. "Quando criança", escreve, "sonhava com um pequeno nicho de mais ou menos um metro de largura

\footnotetext{
39 N. T.: no original: "Ce sont, affirme-t-elle en 1992, deux créatures nées de mon imagination qui m’ont aidée à vivre indépendante et m’ont évité de finir dans une institution psychiatrique. Elles m’ont aussi conduite dans un voyage au cours duquel, bribe par bribe, j'ai finalement réussi à exister en tant qu'être doué de sentiments et d'émotions dans 'le monde', le monde réel”. Ibid., p. 169.

${ }^{40}$ N. T.: no original: "la cassure".

${ }^{41}$ N. T.: no original: "mimer" refere-se diretamente ao que nomeamos a atividade de fazer "mímica" ou "fazer mímica"; remeteria aqui, grosseiramente, a uma "imitação".

${ }^{42}$ N. T.: CE2: corresponderia ao antigo terceiro ano da escola primária.
} 
por um metro de comprimento. A máquina de contenção que, finalmente, construí era meu nicho secreto, desejada em meus sonhos infantis. Por vezes, inquietava-me com a ideia de que a máquina de contenção iria esmagar-me, que não conseguiria mais viver sem ela. Em seguida, dei-me conta de que a máquina era só um aparelho de contenção feito de pedaços de compensado. Era uma invenção que eu havia concebido. Os sentimentos e os pensamentos que me vinham na máquina poderiam existir fora dela. Os pensamentos eram fruto da minha mente - não da máquina de contenção" (Grandin, [1986] 1994, p. 111). Essa máquina reguladora é uma invenção original com base na qual toda existência de Grandin se estrutura por derivação metonímica. Após ter consagrado seu mestrado às máquinas de contenção nos currais, escreve uma tese sobre os efeitos do meio ambiente no comportamento e desenvolvimento do sistema nervoso central dos animais. Depois, trabalha na melhoria de vida do gado, desenhando um material para evitar seu sofrimento, faz comunicações científicas sobre essas questões, dedicando-se a conferências sobre a neurologia dos autistas e sobre os benefícios de sua máquina de espremer para acalmar o sistema nervoso deles. Desde então, sua vida profissional e seus centros de interesse parecem totalmente comandados por sua máquina.

Esta última tem para ela função de "motivação", escreve, constitui uma criação original que lhe permite uma certa contenção de seu gozo. Graças a isso, o funcionamento pulsional se estrutura. Essa contenção possibilita uma certa aceitação da expressão dos sentimentos do sujeito e daqueles que os outros manifestam por ele. Grandin considera que é graças a sua máquina que consegue dominar sua agressividade, a aprender a sentir e a aceitar e receber demonstrações de afeto. Entretanto, nenhuma falta é cavada no campo do Outro, em que o sujeito poderia alojar o objeto perdido de seu desejo: "A máquina de espremer", escreve, "me dá o sentimento de ser carregada, acarinhada, ninada docemente nos braços de Mamãe. É difícil de escrever preto no branco, mas é também uma maneira de aceitar esse sentimento" (Grandin, [1986] 1994, p. 119). Essa máquina não é o índice de uma falta, como seria um objeto transicional, ao contrário, preenche o sujeito, gera um imaginário incestuoso, de modo que fica extremamente claro que, para Grandin, o objeto $a$ encontra-se incluído em uma borda protetora.

O autista mascara a perda simbólica e se adapta a ela graças a um objeto que, evidentemente, encarna o duplo: Tustin nota isso, Williams e Joey o confirmam claramente. Ora, não é assim no que concerne a Grandin. Ela construiu um objeto autístico particularmente complexo: sua máquina não é um duplo dela mesma, em revanche, constrói-se a partir do duplo. 
Grandin não esconde o fato de se identificar com os animais para os quais as máquinas foram construídas. Inicialmente, em um rancho de sua tia Ann, no Arizona, ela quis se colocar no lugar de um deles. "Posto que a pressão do contato tátil acalmava os bezerros, pergunta-se se não poderia ter a mesma sensação. "Primeiro", relata, "regulei a barreira para que se ajustasse à altura de minha cabeça quando eu ficava de quatro; em seguida, subi no curral e Ann puxou a corda que segurava as bordas da máquina para o gado para aproximá-las [...] O resultado era, ao mesmo tempo, de estimulação e descontração [... ] A máquina de contenção aliviava minhas crises de nervos" (Grandin, [1995] 1997, p. 108). Mais tarde, quando observa o funcionamento de uma máquina de contenção em um abatedouro, observa, "identificava-me ao animal" (Grandin, [1995] 1997, p. 146). Além disso, queria intitular seu segundo livro "O ponto de vista de uma vaca". "Meus esquemas de pensamento visual", afirma nesse livro, "são de fato mais próximos daqueles dos animais do que dos pensadores verbais" (Grandin, [1995] 1997, p. 184).

Qual é o tratamento de seu duplo operado pelo objeto autístico complexo? O aparelho que capta, inicialmente, sua atenção, serve, nos diz, "para segurar um animal a fim de marcá-lo, vaciná-lo ou castrá-lo”, mais tarde, ela se especializa em máquinas para gado usadas para conduzir os animais ao matador ${ }^{43}$ nos abatedouros. Não existe nenhum acaso nisso, posto que, desde sua infância, o projeto de máquina para o bem-estar se elaborava em torno de uma "espécie de caixa parecida com um caixão" (Grandin, [1986] 1994, p. 51). É muito importante para ela, sublinha, dominar a ligar e o desligar de sua máquina. Esta lhe serve, então, como as de Joey, para introduzir um corte no gozo desregulado. A máquina para gado de Grandin é construída a partir de uma antecâmara da morte, com a qual encena o controle de sua própria perda e é por isso que comporta uma dimensão inquietante, completamente incompatível com os "doudous" que ela nunca teve. Com frequência, confessa, "eu tinha sentimentos ambíguos vis-à-vis da máquina para gado" (Grandin, [1986] 1994, p. 131) [...] em meu interior, negava sua origem rude e crua". Assim, não é surpreendente que tenha podido afirmar: "A morte nos abatedouros é muito mais suave do que a morte natural [...] se eu pudesse escolher, preferiria passar por um matadouro industrial em vez de ter, ainda viva, minhas tripas arrancadas por coiotes ou leões" (Grandin, [1995] 1997, p. 238). Sobre isso, sublinhamos novamente, que os objetos autísticos não funcionam como sedativos tais como os objetos transicionais. Esses últimos dão testemunho de uma simbolização apaziguadora da falta, enquanto que a falicização falha dos objetos autísticos deixa entrever, de algum modo, a

\footnotetext{
${ }^{43}$ N. T.: no original: "étourdisseur", que designa aquele que abate os animais nos abatedouros.
} 
conexão deles com o objeto real, que comanda a pulsão de morte. A proteção que a borda oferece em relação ao Outro gozador permanece frágil.

Grandin se coloca no lugar dos animais, enquanto, correlativamente, os humaniza. Pensa que eles têm uma alma "pois a estrutura de base do cérebro é similar". O último capítulo de Penser en images é consagrado à sua relação com a religião. Ali, explica ter chamado a máquina para gado, que construiu em 1974 nos abatedouros Swift, de "a escada do Paraíso" porque se constituía "na entrada dos céus para o gado" (Grandin, [1995] 1997, p. 232). Graças à construção desse aparelho, e conforme o modo de pensamento concreto dos autistas, ela pode apreender as abstraçōes religiosas. "Descobri Deus", escreve ela, "no alto da escada do Paraíso. Nos abatedouros Swift, as crenças se verificaram na realidade. Não era mais só uma discussão intelectual. Olhava os animais morrerem, eu mesma matei alguns deles. Ninguém teria motivo para ser virtuoso, se só existisse um buraco negro no alto da escada do Paraíso". A máquina para gado servia-lhe para tratar concretamente a hiância do Outro: Grandin pacifica o buraco negro fazendo de sua máquina uma "escada do Paraíso" no alto da qual se encontra Deus. Ela pensa ter achado, por intermédio disso, um sentido para a vida e não mais temer a morte. Grandin não hesita em confessar que comparava, então, os abatedouros Swift com o Vaticano: um imaginário paterno surge quando ela constrói uma máquina para obturar a hiância do Outro. "Quando a força vital abandonava o animal, eu sentia", afirma ela, "profundos sentimentos religiosos [...] Creio que o lugar onde um animal morre é sagrado [...] Queria reinstaurar uma forma de ritual nos abatedouros". Chega, assim, a abordar a questão da perda simbólica por intermédio de seu duplo animal. Encontra aí a intuição das grandes religiões: Deus é convocado sempre por um sacrifício a um Outro obscuro. Entretanto, Grandin não realiza esse sacrifício, ela só pode encenar a iminência dele quando se aloja em sua máquina. "Se não houvesse a morte", escreve, "não se saberia apreciar a vida" (Grandin, [1995] 1997, p. 231). Lembremos que o primeiro projeto da máquina do bem-estar, concebida no CE2, já era "uma espécie de caixa parecida com um caixão". Com seu objetoborda, o autista trata a castração, mas sua recusa da alienação significante e sua preocupação em manter o controle sobre o objeto de gozo não lhe deixam outra solução a não ser colocá-la em imagem.

A "escada do Paraíso" construída nos abatedouros Swift é uma das versões da máquina do bem-estar. Ela produz, como os objetos de Joey, uma regulação da energia vital por intermédio da ligação controlada com um objeto de gozo. Quando Grandin é separada disso, tem a experiência de uma perda, mas conserva a possibilidade, "acomodando-se" em sua máquina, de restaurar 
uma completude imaginária. É o ligar-se e desligar-se que introduz um corte regulador na economia libidinal.

Confrontar-se com a hiância do Outro, nem que seja por intermédio de um duplo animal que se esforça por obturá-la, constitui uma tarefa de extrema dificuldade para um sujeito autista. Quatro anos depois da construção da escada do Paraíso, Grandin realiza "um golpe de publicidade estúpido", que a torna conhecida, mas desorganiza suas defesas, o que ela coloca na conta dos "organophosphates" ${ }^{44}$ com os quais teria tido contato na época. Temporariamente, seu sentimento religioso desaparece, o que a adoece gravemente. Ela o restaura graças à Física quântica, que parece fornecer a ela "uma base científica plausível para a crença na imortalidade da alma e no sobrenatural [...]. Na natureza", explica, "as partículas estão misturadas com milhôes de outras partículas, cada uma interagindo com todas as outras partículas. Pode-se imaginar que esse emaranhado de partículas esteja na base de uma consciência universal. É minha concepção atual de Deus" (Grandin, [1995] 1997, p. 236). Elabora, sobre isso, um modo de abordagem da hiância do Outro a partir de sua borda, que evita o confronto com a questão do sacrifício. É a solução espinozista, esse panteísmo, sublinha Lacan "que nada mais é do que a redução do campo de Deus à universalidade do significante, de onde se produz um distanciamento sereno, excepcional, em relação ao desejo humano" (Lacan, 1973, p. 247). Como a perda não é mais necessária, surgem, então, ideias de imortalidade. "As ideias se transmitem como os genes", afirma Grandin, "e tenho muita vontade de divulgar minhas ideias". Confessa que escreve porque "as bibliotecas são o único lugar do mundo onde temos acesso à imortalidade", esta, prossegue, "é, talvez, o efeito que nossas ideias tem nos outros" (Grandin, [1995] 1997, p. 235). Tratando a hiância do Outro exclusivamente a partir do simbólico, sem colocar em jogo a questão da perda, nem a do objeto de gozo, produz-se um apaziguamento intelectual, mas a energia pulsional não vem daí: a máquina de contenção e sua encenação imaginária da perda permanecem sendo o que a mobiliza.

No sujeito autista, os objetos autísticos complexos são testemunhos de um saber em jogo sobre a castração: ele tem a intuição de que é preciso passar pela encenação imaginária da perda de um objeto de gozo para animar seu funcionamento. São fundamentalmente objetos dinâmicos usados para remediar o sentimento de falta de energia do sujeito autista, em particular quando se trata de se expressar por si mesmo. O duplo do autista é uma

\footnotetext{
${ }^{44}$ N. T.: mantivemos o termo no francês, pois não encontramos similar em português; no Le Petit Robert, consta do termo “organophosphoré, ée [organofosfore] adj. et n. m. • 1955; de organo- et phosphoré". Química. Diz-se de um produto orgânico de síntese, contendo carbono e fósforo. Insecticide organophosphoré.
} 
imagem dinâmica que encerra e mascara o objeto $a$ não negativizado pela função fálica, o que o torna atrativo, mas o deixa às voltas com a pulsão de morte, daí a relação por vezes ambivalente do sujeito com ele. Acontece do autista, temporariamente, odiar sua dependência a seu objeto. Williams nota, pertinentemente, que a energia sem limite de seus companheiros imaginários origina-se na "angústia e no pânico" (Williams, 1992, p. 239).

Seria redutor apreender os objetos autísticos complexos, que compõem um dos elementos da borda, referindo-os a uma simples encarnação do duplo, como os Lefort são tentados a fazer, em sua última obra. Eles não dão aos objetos autísticos um lugar principal, posto que consideram que o autista não pode extrair nenhum objeto no Outro, que permanece real e intocado. Com base nisso, é necessário que apreendam o objeto autístico, essencialmente, por intermédio do duplo, o que fazem desde o "marinheiro" de Marie-Françoise, sob o modo de um duplo real, tendo, essencialmente, uma função de tapaburaco (Lefort, 1980, p. 315). Mas, isso faz deles objetos nocivos? A posição dos Lefort parece menos radical. Observam, com grande pertinência, que o duplo é usado para remediar a divisão do sujeito. No autismo, afirmam, "a ausência de divisão do sujeito, que não entra no significante sequencial da linguagem nem se representa por um $S 1$, leva à ausência correlativa de um resto $(a)$. É o que o sujeito tampa pela via de seu duplo, isto é, do mesmo, sem separação, posto que, desde o início, falta a alienação" (Lefort, 2003, p. 61). Com base nisso, ao consagrar algumas páginas a Temple Grandin, constatam que a encarnação animal que ela faz do duplo tem papel central em sua autoterapia. O duplo, observam no final do capítulo, "pode ter função de suplência, muito mais eficaz que a que pode encontrar o psicótico, que uma dependência cola a seu Outro e ao objeto que, no real, deve a esse Outro. O duplo está também no real, mas pode fazer a separação com o Outro" (Lefort, 2003, p. 62). A nocividade do marinheiro de Marie-Françoise é temperada pela evidência da função autoterapêutica do duplo para Grandin. Entretanto, os Lefort não se estendem sobre a especificidade da estabilização de Grandin, não elaborada diretamente com base em seu duplo animal, mas de uma maneira de tratálo, construindo a máquina de contenção. Levando isso em conta, verifica-se mais claramente que os objetos autísticos complexos, apoiando-se no duplo, permitem um enquadramento do objeto de gozo. Disso resulta um efeito de dinâmica subjetiva que nem Tustin nem os Lefort levaram em conta.

Uma das formas mais elaboradas do objeto autístico complexo é, sem dúvida, aquela a qual chega Donna Williams após ter abandonado seus companheiros imaginários. O duplo autístico se apaga, pois se prende, então, à imagem no espelho. Ela descreve o fenômeno com um certo talento literário. 
"Eu apreciava”, confessa, no final de sua segunda obra, "ter tanto tempo para mim e me possuir integralmente sem personagens. Corri para o banheiro. 'Bom-dia', diziame eu diante do espelho. Pintei um espelho pendurado na parede do saláo, com capim alto em primeiro plano e uma moldura de roseiras trepadeiras selvagens de todas as cores. Deitava-me na frente dele, de modo a parecer deitada no capim alto do mundo invertido; o Sol do quadro brincava loucamente com o capim e lhe dava todas as nuances de verde, dourado e marrom. Levava, por vezes, minha refeição para almoçar comigo no espelho. Nós ficávamos sentadas, as duas, no belo capim selvagem, alto e em movimento. Juntas, cercadas de rosas, não havia mais do que eu e eu no espelho. Sem lugar. Sem mundo. Sem solidão. Os outros não eram mais também tão importunos desde que eu passava tanto tempo comigo" (Williams, [1994] 1996, p. 275).

Apoiando-se em uma imagem no espelho magnificente, o duplo autístico dá estofo ao eu do sujeito, sua falicização se acentua, mas é uma falicização que não passa pela castração. O duplo escópico de Williams não cessa de ser obstáculo a qualquer acesso à falta do Outro, ela nota finamente que seu duplo não dá lugar a seu ser, por não poder alojá-lo no campo do Outro. Não é, também, um canal em direção ao mundo: isola-a em reflexos narcísicos, em uma solidão povoada por ela mesma. Coloca, entretanto, o objeto olhar a distância, capta-o. E dá a Williams o sentimento de não ter "nunca se sentido tão totalmente viva" (Williams, [1994] 1996, p. 314). Mesmo que com alguma dificuldade, ela pode tecer "um laço precioso" com um companheiro, mas com a condição de que ele compareça no lugar do duplo. É por isso que, durante longo tempo, as únicas relaçôes que pode estabelecer com um homem só se produzem com autistas de alto desempenho. Ao final de sua segunda obra, relata o encontro com Ian, com o qual se estabelece uma relação de "pertencimento" que ambos querem que seja "assexual e platônica" (Williams, [1994] 1996, p. 295). Ela se casa com ele, em seguida, mas se separa dois anos depois.

Chega, então, a conhecer algo a que muito poucos autistas têm acesso: o gozo sexual com um parceiro. Constata-se que isso só tinha sido possível por ocasião de seus primeiros encontros sentimentais com parceiros não autistas: primeiro, com Mike, depois com uma mulher, Shelly, e com o segundo marido, Chris (Williams, 2004). Sem dúvida, para que ela sentisse, por empatia, o gozo orgástico, foi preciso encontrar duplos capazes de apreendê-la como autêntico objeto de gozo. Para eles, ela não era um duplo, mas um objeto apto a preencher a falta do desejo deles.

O canal do duplo é uma via privilegiada para que uma transferência se estabeleça com um sujeito autista e o tratamento efetuado por Williams com Mary confirma isso. De modo que corre o risco, certamente, de cair na ambivalência destrutiva. Mas a experiência mostra que isso não é inevitável se o analista sabe apagar sua 
presença, prestando-se, ao mesmo tempo, a servir de objeto dinamizador. $\mathrm{O}$ estilo de relação que se atualiza no tratamento é similar ao que se observa na ligação estabelecida pelo autista com o facilitador da comunicação assistida ${ }^{45}$. Ora, se este encarna demais a posição do duplo, acaba por nutrir ilusões de fusão telepática que, por vezes, suscitam uma transferência negativa geradora de ideias de intrusão, até mesmo de sedução abusiva.

A transferência autística pode se apoiar em objetos da mesma natureza que os objetos autísticos complexos, uns e outros vêm no lugar do duplo, de modo que eles não são os objetos nocivos e devastadores teorizados por Tustin. Essa negligenciou o traço dinâmico do que eles possuem. O sujeito busca assimilar essa propriedade, mas isso só é possível operando um trabalho que se apoia no objeto e passa por uma elaboração imaginária da perda simbólica. "O homem pensa com seu objeto", sublinhava Lacan, comentando o Fort-Da freudiano (Lacan, 1973, p. 60). O autista tem uma intuição confusa disso, adivinha até que, desse objeto, seria preciso automutilar-se para animar seu ser e regular o gozo. Ele consegue, por vezes, encenar isso, mas não realizá-lo.

\section{Referências}

Axline V. Dibs. (1967). Paris: Flammarion.

Bettelheim B. (1969). La forteresse vide. Paris: Gallimard.

Freud S. (1975). Au-delà du principe de plaisir. In: Essais de psychanalyse. Paris: Payot.(Texto original publicado em 1920).

Grandin T. (1997). Penser en images. Paris: O. Jacob.

Grandin T. (1994). Ma vie d'autiste. Paris: O. Jacob.

Guillas G. Que l'Autre soit, in Du changement dans l'autisme?. Journée de l'ACF/VLB du 27 mars 1999.

Hemsley $\mathrm{R}$ et coll. Le traitement des enfants autistes dans l'environnement familial. In: Lacan J. Le désir et son interprétation. Séminaire inédit. Séance du 6 Juin 1959.

Lacan J. (2001). L'acte psychanalytique. Compte-rendu du séminaire 19671968. In: Autres Ecrits. Paris: Seuil.

\footnotetext{
${ }^{45}$ N. T.: no original: "le facilitateur de la communication assistée".
} 
Lacan J. (1973). Les quatre concepts fondamentaux de la psychanalyse. Le séminaire XI. Paris: Seuil.

Lefort R. et R. (1980). Naissance de l'Autre. Paris: Seuil.

Lefort R. et R. (2003). La distinction de l'autisme. Paris: Seuil.

Lemay M. (2004). L'autisme aujourd'hui. Paris: O. Jacob.

Miller G. et D. L'enfant-machine, in Ornicar? Revue du champ freudien. 1984, 31.

Peeters T. (1996). L'autisme: de la compréhension à l'intervention. Paris: Dunod.

Rutter M. Schopler E. (1991). L'autisme: une réévaluation du concept et des traitements. Paris: PUF.

Sacks, O. (2008). Um antropólogo em Marte. São Paulo: Companhia de Bolso.

Sutton N. (1995). Bettelheim. Paris: Stock.

Tammet, D. (2006). Born on a blue day. London: Hodder.

Tustin F. (1977). Autisme et psychose de l'enfant. Paris: Seuil.

Tustin F. (1986). Les états autistiques chez l'enfant. Paris: Seuil.

Tustin F. (1992). Autisme et protection. Paris: Seuil.

Williams D. (1992). Si on me touche, je n'existe plus. Paris: Robert Laffont.

Williams D. (1996). Quelqu'un, quelque part. Paris: J'ai Lu.

Williams D. (2004). Everyday heaven. London; New York: Jessica Kingsley.

Winnicott D. W. (1969). Objets transitionnels et phénomènes transitionnels. In: De la pédiatrie à la psychanalyse. Paris: Payot. 